\title{
WHEN POLITICS IS QUOTED ON THE STOCK MARKET. CASE STUDY - ROMANIA
}

\author{
Diana Elena VASIU \\ diana.vasiu@ulbsibiu.ro \\ “LUCIAN BLAGA” UNIVERSITY, SIBIU, ROMANIA
}

\begin{abstract}
The stock markets are considered to be the most sensitive markets, the variation of the titles course being generated by multiple objective and subjective factors. When social or political events take place, the stock market is rising or falling, and the press takes over and disseminates this information. Starting from this context, we analyze the measure in which the Bucharest Stock Exchange (BSE) reacted at times agitated from a social and political point of view, in the last period.
\end{abstract}

\section{KEYWORDS:}

BSE Index, Stock Markets, Titles Variation

\section{Introduction}

In the national financial markets, imbalances in some markets can also be conveyed on the other, thus emphasizing the effects on the overall balance. The manifestation of imbalances in the financial markets results in the general decrease of stock exchange rates as a result of the change in investors' perception of the value of the issuing enterprises (Dragotă, 2009).

At the same time, within the national capital markets, there are deep institutional links that seek political change. As part of the financial system, the capital market reflects cyclicality in the economy, identifying stock cycles (Dragotă, 2008).

Since the main role of a stock index is to have an impact on the overall market evolution to which it refers (Anghelache, 2009), representing the average price of all titles, or just the most representative securities listed on the stock exchange (Stancu, 2007), we chose to research the evolution of Bucharest Stock Exchange, by means of some representative indices: BET, BET XT, ROTX and BETFI indices.

For this analysis, we chose the period 2014-2017, marked by significant political changes: the presidential and local elections, the change of several governments, the ministry reshuffle, the accident at Colectiv, the January-February 2017 streets protests.

\section{The context}

The time frames taken into consideration were:

- The presidential elections in November 2014 and in particular the days of $2^{\text {nd }}$ of November 2014 and $16^{\text {th }}$ of November 2014, when the two rounds of voting took place

- The local elections in June 2016

- Parliamentary elections December 11,2016 , announcement of final results and government formation, marked by a rejection of the nominated prime minister 
- Government changes. Victor Ponta's Government (2) was the cabinet that ruled Romania from December $21^{\text {st }}, 2012$, when it received the vote of confidence of the Romanian Parliament and sworn in and until March $5^{\text {th }}, 2014$. On February 11, 2014, a new political crisis began, with USL leaders initiating discussions on restructuring the government. On February 25 ${ }^{\text {th }}$, 2014, the USL broke up and the PNL decided to leave the government. The Government of Victor Ponta (2) was dissolved and after ten days the Victor Ponta Government (3) was established. Victor Ponta's Government (3) ruled Romania since March $5^{\text {th }}$, 2014, after having received Parliament's vote of confidence the day before. The Ponta Government (3) was supported by PSD, UDMR, PC and UNPR and remained in office until after the presidential elections of that year. When UDMR withdrew from the government a new government led by the same Prime Minister, Victor Ponta, was invested on December $17^{\text {th }}$. Victor Ponta's Government (4) was Romania's executive since December $17^{\text {th }}, 2014$, given that two days before he had received the parliamentary vote of confidence, until November $4^{\text {th }}$, 2015, when Prime Minister Victor Ponta resigned, following the incident at the Club Colectiv. Dacian Cioloş Technocratic Government followed, who ruled Romania from November $17^{\text {th }}, 2015$, until January $4^{\text {th }}, 2017$. The government of Sorin Grindeanu ruled Romania from January $4^{\text {th }}$ to June $29^{\text {th }}, 2017$, when he was dismissed on grounds of inefficiency. The Government of Mihai Tudose followed, headed by Mihai Tudose, who took over as prime minister of Romania on June $29^{\text {th }}, 2017$.

- The fire from the Club Colectiv on the night of Friday October $30^{\text {th }}, 2015$. The size of the event and the large number of casualties has prompted the Ministry of Internal Affairs to establish the Red Plan of Intervention, and the Romanian Government has decreed three days of national mourning. The event had a particular social impact, irregularities in the health system and the slow reaction of the authorities, which led to an increase in the number of victims, generated massive protests that ended with the resignation of Prime Minister Victor Ponta on November $4^{\text {th }} 2015$, together with his government, and Mayor of District 4 in Bucharest, Cristian Popescu Piedone.

- Street protests triggered by the intentions of the Grindeanu government on amnesty and amendment of the Penal Code. On the first day, on January $18^{\text {th }}$, around 5,000 people showed up, out of which nearly 4,000 were in Bucharest. The protests lasted more than a month, reaching the peak on Sunday evening, February $5^{\text {th }}$, when more than 500,000 demonstrators protested across the country, despite the fact that earlier that day the government had announced the repeal of GEO no. 13.

In view of these developments, the events with the strongest impact took place in March and November-December 2014, November 2015, June 2016, NovemberDecember 2016, January-February 2017, June 2017.

In order to analyze how these events had an impact on the evolution of the Bucharest Stock Exchange, we analyzed the fluctuation of the representative indices BET, BETX, ROTX, BETFI, analyzing daily variations.

\section{Case study}

Research hypothesis: The study of the variation of BVB indices in the context of socio-political events is based on the following hypothesis: The important socialpolitical events have a major impact on the evolution of the Stock Exchange, generating significant variations in the exchange rate of traded securities and further, in indices quotes.

Research objectives: The main objective of the research is to analyze the variation of the BVB representative indices BET, BETX, ROTX, BETFI at the time of important social-political events.

Research methodology: In order to analyze how these events had an impact on the evolution of the Bucharest Stock 
Exchange, we analyzed the variance of BVB representative indices BET, BETX, ROTX, BETFI. Daily indices values were taken from www.bvb.ro. Index variation was assessed by daily BSE index changes, calculated as a percentage change in the current day value as compared to the value recorded on the previous day.

\section{Analysis of data and presentation of results: \\ March 2014 - Government changes \\ Evolution of indexes analyzed in} February 2014 is shown in Figures no. 1, 2, 3 and 4:

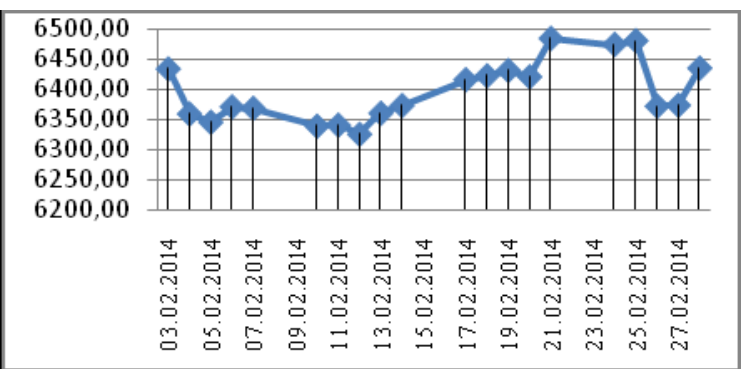

Figure no. 1 BET index evolution in February 2014

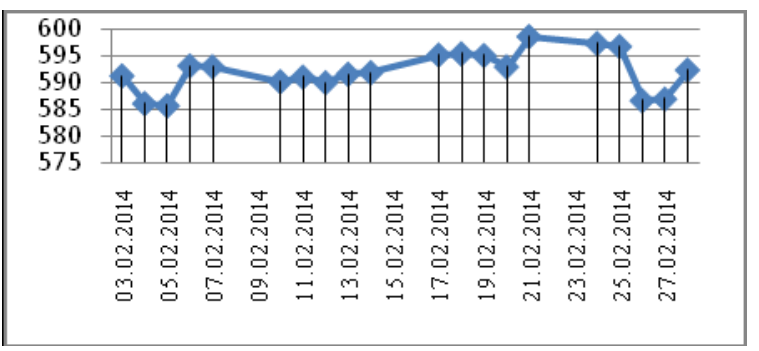

Figure no. 2 BET XT index evolution in February 2014

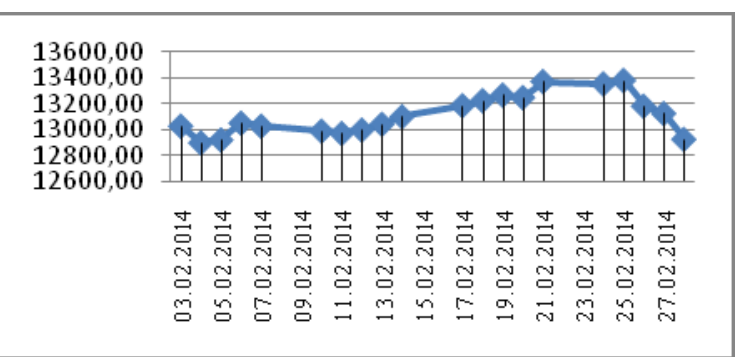

Figure no. 3 ROTX index evolution in February 2014

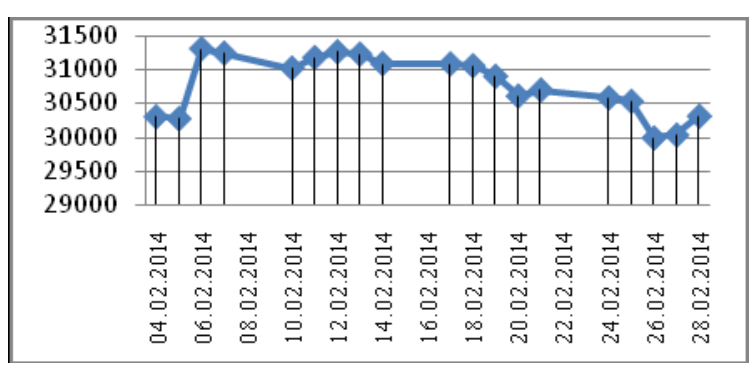

Figure no. 4 BETFI index evolution in February 2014

It is noteworthy that all indices recorded a daily decrease in the period 24-25-26 February 2014, the moment of USL rupture and the exit of PNL from the government.

Regarding the evolution of daily variations, these are presented in the Figure no. 5:

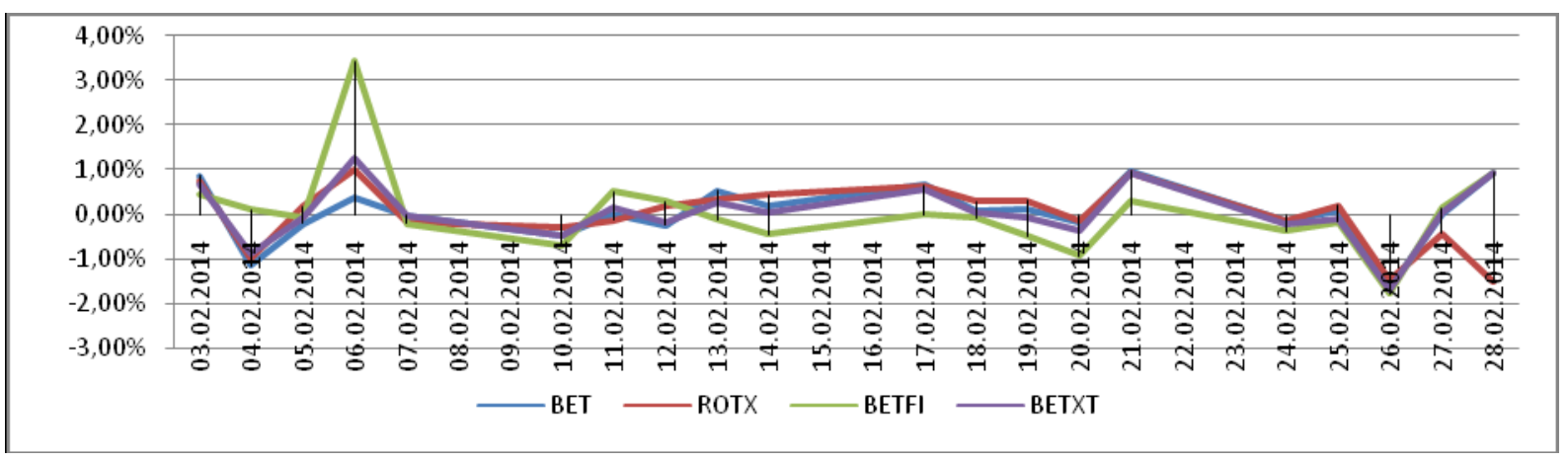

Figure no. 5 Evolution of daily BSE index changes in February 2014 
Although the daily variations of the BVB indices analyzed were oscillating, however, some of the greatest decreases compared to the previous day were recorded for all indices on February $26^{\text {th }}$, 2014 , the day after the announcement of the USL rupture.

\section{November 2014 - Presidential elections}

Evolution of the indices analyzed in November 2014 is shown in Figures no. 6, 7,8 and 9:

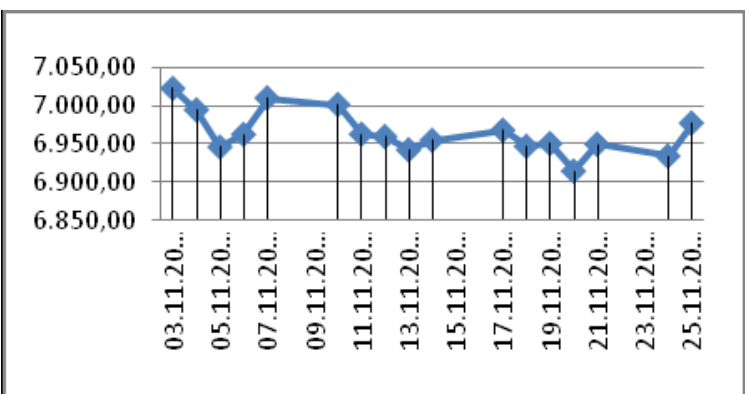

Figure no. 6. BET index evolution in November 2014

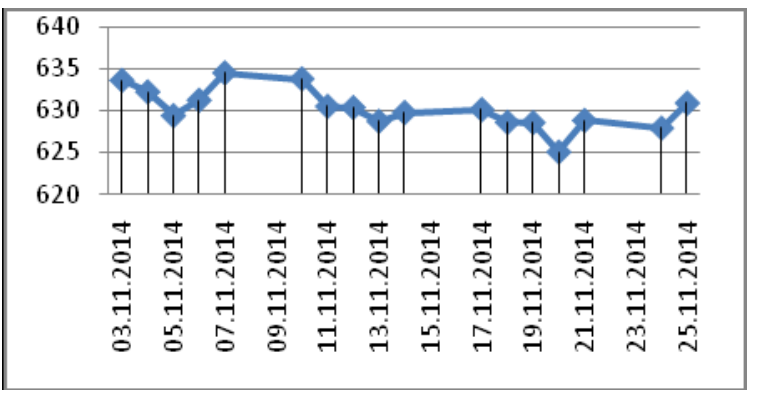

Figure no. 7 BET XT index evolution in November 2014

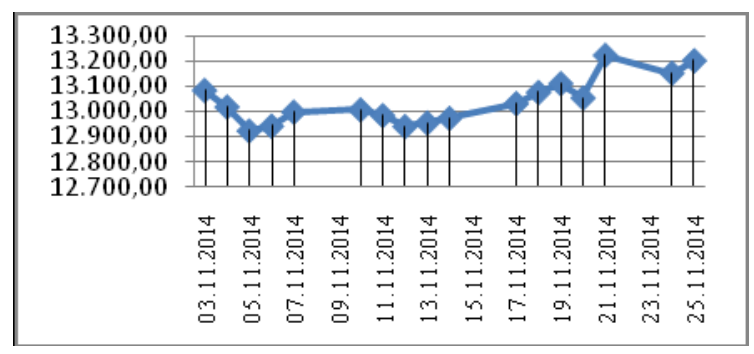

Figure no. 8. ROTX index evolution in November 2014

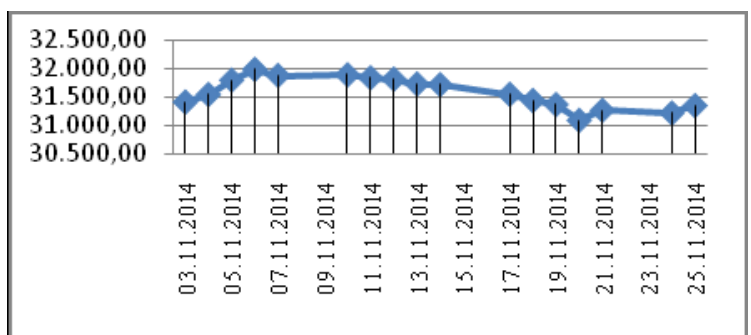

Figure no. 9 BETFI index evolution in November 2014

As can be noted, the indices analyzed had relatively identical behavior, each of them decreasing, the minimum value being recorded at the second ballot. The fall in index values began with the first ballot, with social and political instability being fueled by the Diaspora's manifestations of voting abroad. The exception was made by ROTX, whose minimum value was reached at the time of the first poll.

Regarding the evolution of daily variations, these are presented in the Figure no. 10:

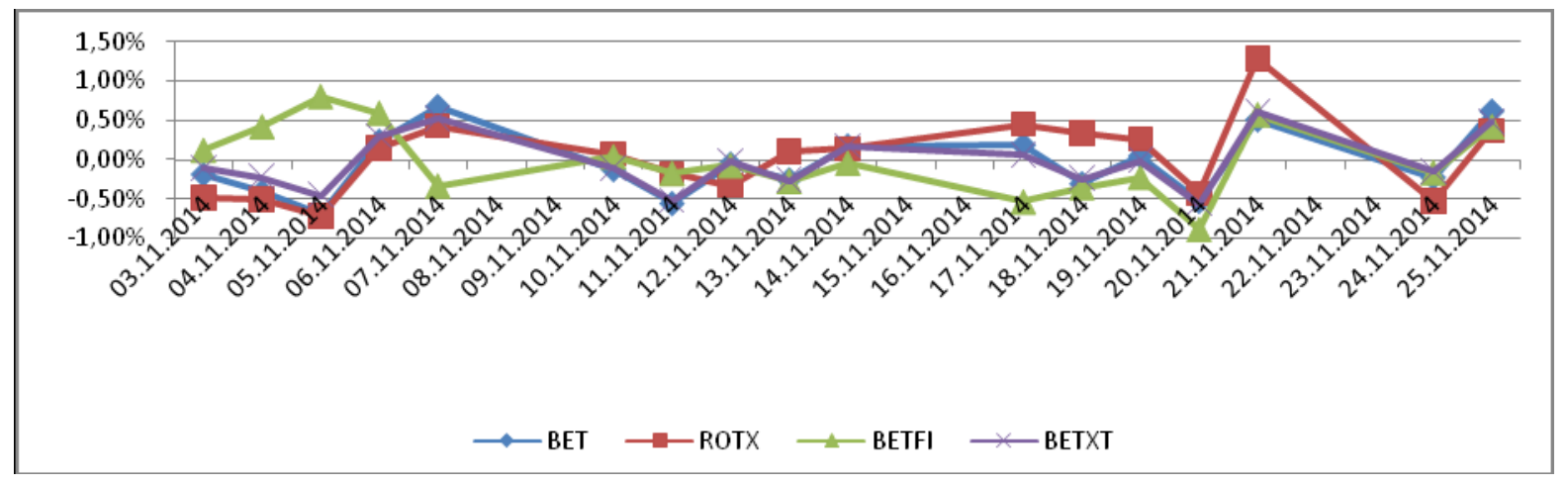

Figure no. 10 Evolution of daily BSE index changes in November 2014 
Regarding the evolution of daily variations, it is noted that the largest decreases compared to the previous day occurred in all cases on the $20^{\text {th }}$ of November 2014, the period that followed the second round of elections and the announcement of the result of the presidential elections.

\section{November 2015 - After the "Colectiv" events and government changes}

Evolution of the indices analyzed in November 2015 is shown in Figures no. 11, 12, 13 and 14:

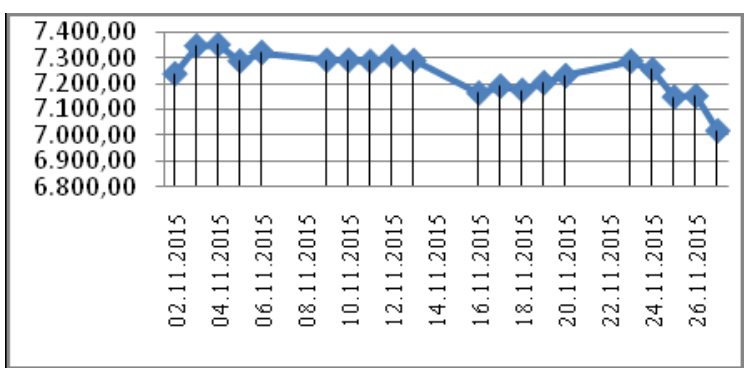

Figure no. 11 BET index evolution in November 2015

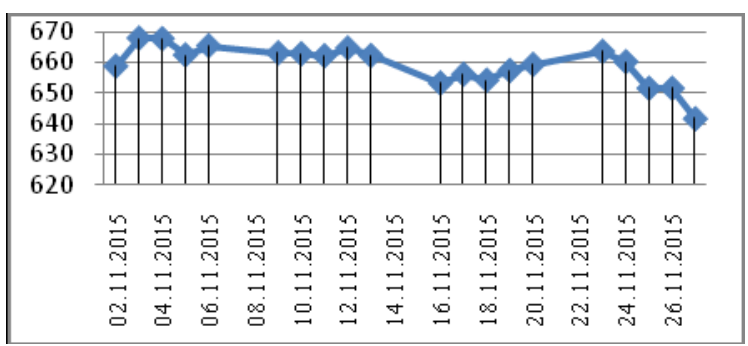

Figure no. 12 BET XT index evolution in November 2015

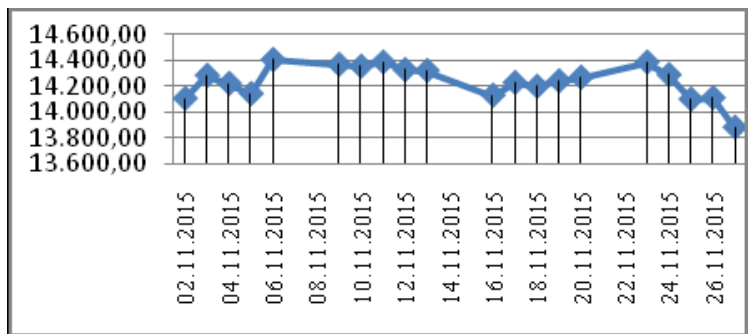

Figure no. 13 ROTX index evolution in November 2015

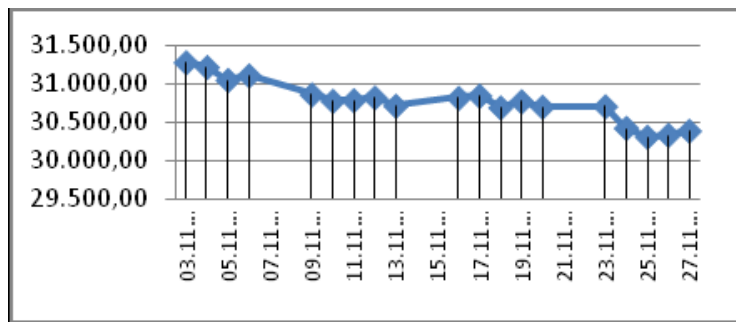

Figure no. 14 BETFI index evolution in November 2015

The stock indices analyzed had different evolutions: the BETFI index recorded a downward trend throughout November, while BET, ROTX and BET XT declined during the political crisis, followed by an oscillating evolution, i.e. an increase immediately after the introduction of the Cioloş government and a further decline towards the end of the month.

Regarding the evolution of daily variations, these are presented in the Figure no. 15:

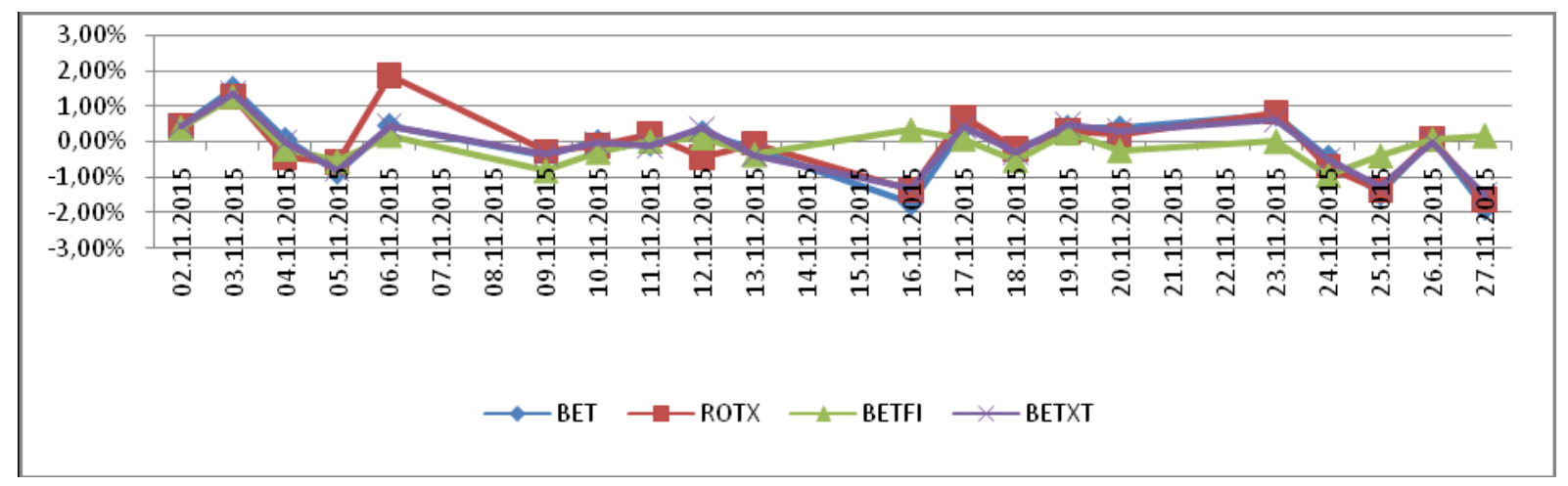

Figure no. 15 Evolution of daily BSE index changes in November 2015 
Regarding the evolution of daily variations (figure 15), it is noted that the largest decreases compared to the previous day took place, except for the BETFI index, on November $16^{\text {th }} 2015$, the day before the appointment of the Cioloş government.

\section{June 2016 - Local elections}

Evolution of the indices analyzed in June 2015 is shown in Figures no. 16, 17, 18 and 19:

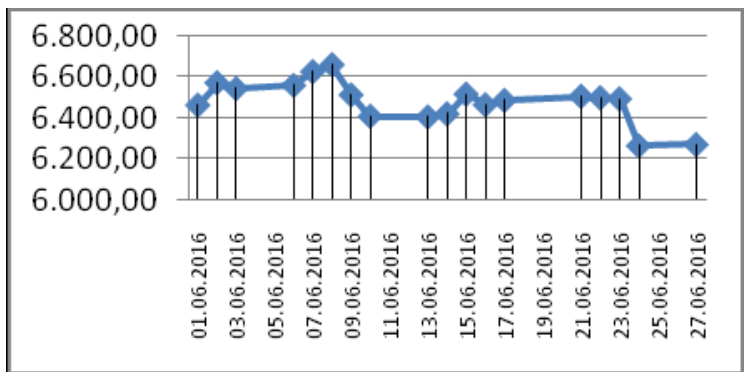

Figure no. 16 BET index evolution in June 2016

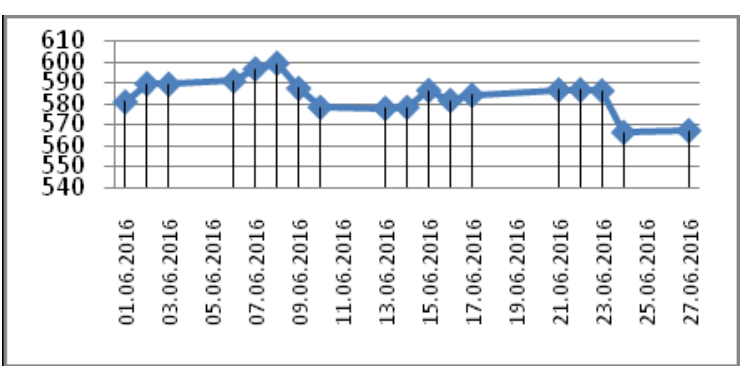

Figure no. 17 BETXT index evolution in June 2016

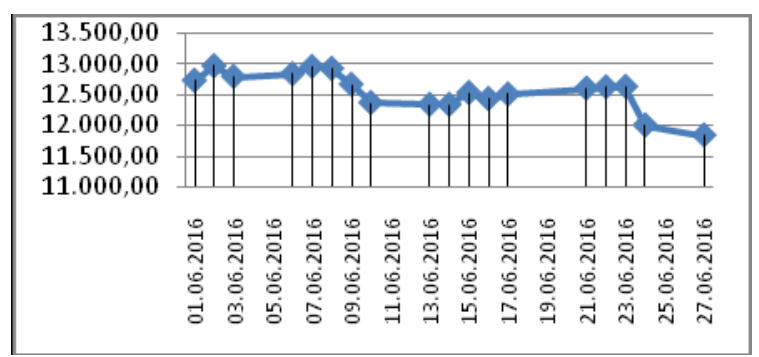

Figure no. 18 ROTX index evolution in June 2016

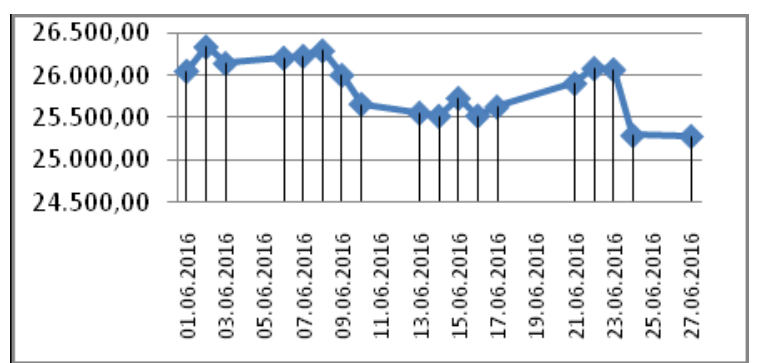

Figure no. 19 BETFI index evolution in June 2016

It cannot be considered that the moment of local elections 2016 would have had a particular impact on the evolution of the BSE indices. Index values suffered diminished values after the local elections and respectively the announcement of the results.

Regarding the evolution of daily variations, these are presented in the Figure no. 20:

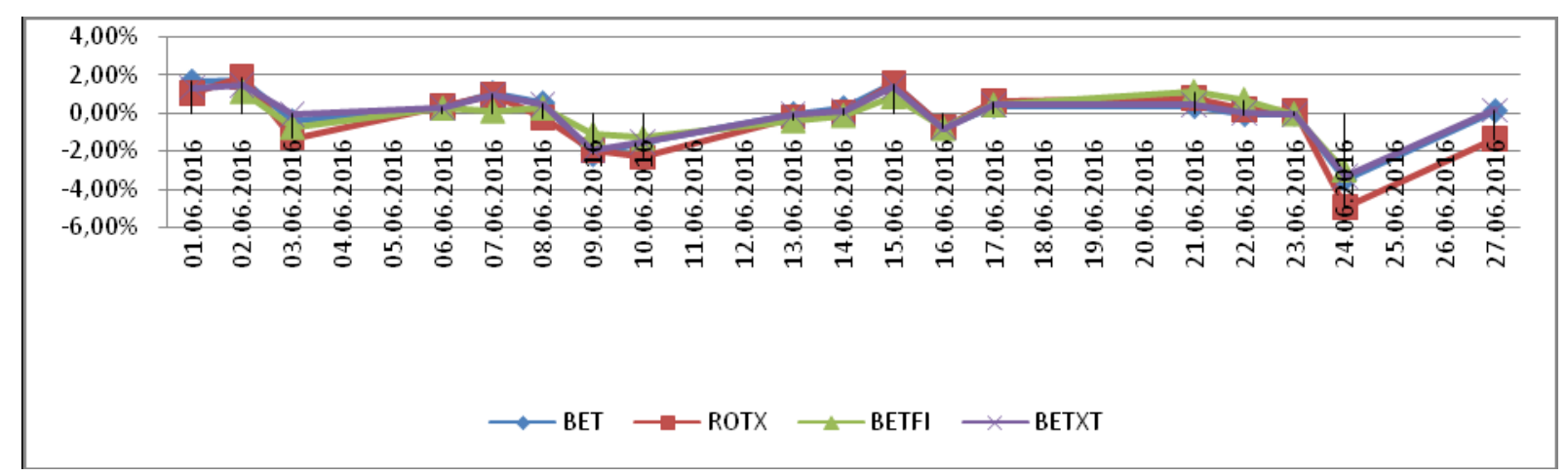

Figure no. 20 Evolution of daily BSE index changes in June 2016 
Regarding the evolution of daily variations, the same thing is noticed, namely that the highest daily variations did not coincide with the moment of the local elections.

December 2016 - Parlamentary elections

Evolution of the indices analyzed in November 2016 is shown in Figures no. 21, 22, 23 and 24:

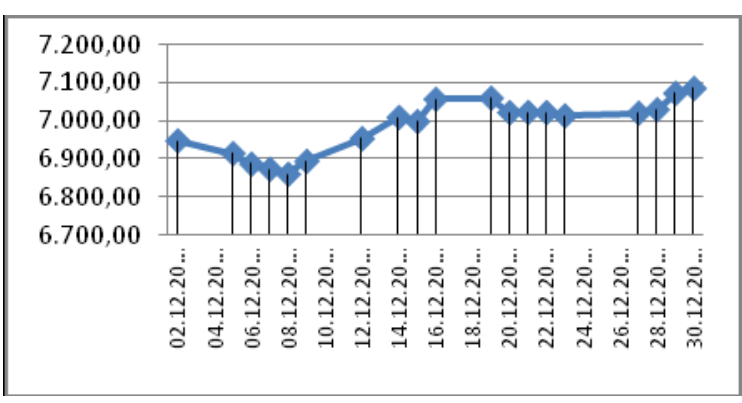

Figure no. 21 BET index evolution in December 2016

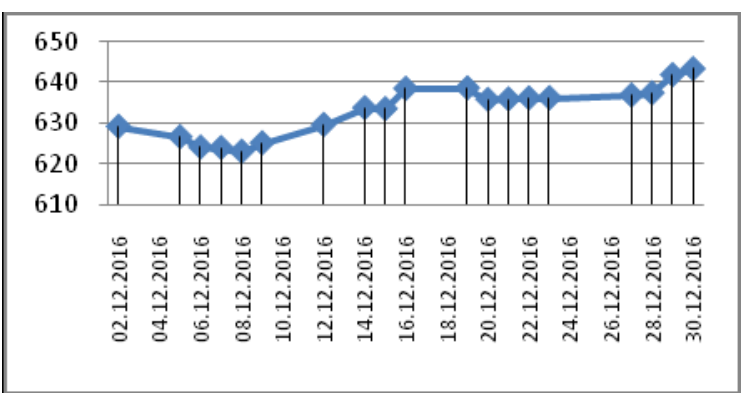

Figure no. 22 BETXT index evolution in December 2016

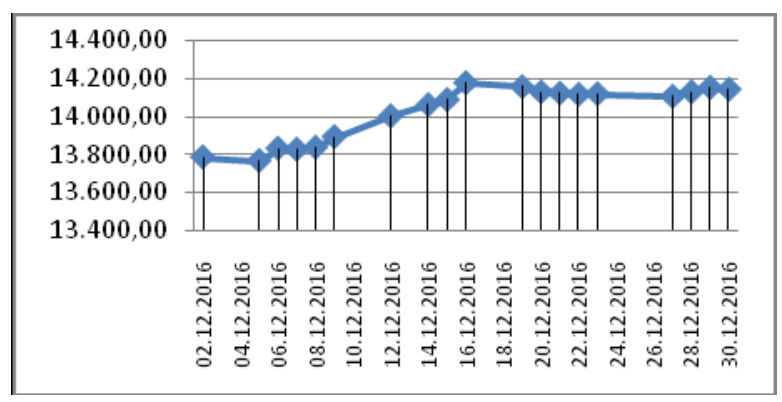

Figure no. 23 ROTX index evolution in December 2016

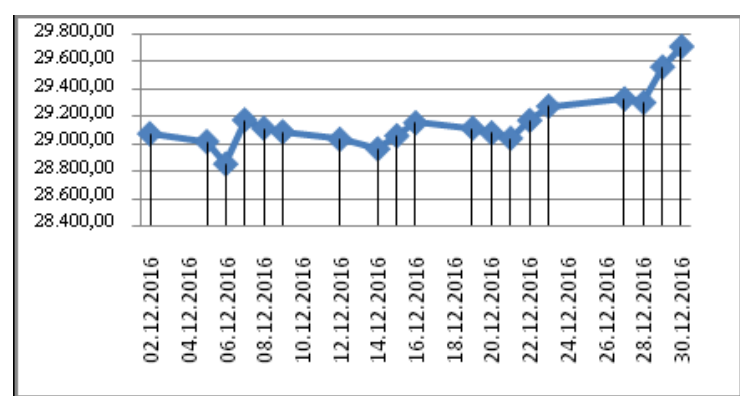

Figure no. 24 BETFI index evolution in December 2016

For BETFI, the same as with the local elections, the timing of the parliamentary elections did not have a clear impact on the indicators analyzed, the decreases in daily values having occurred before the date of the parliamentary elections. For BET, BETXT and ROTX indices the values increases after parliamentary elections.

Regarding the evolution of daily variations, these are presented in the Figure no. 25:

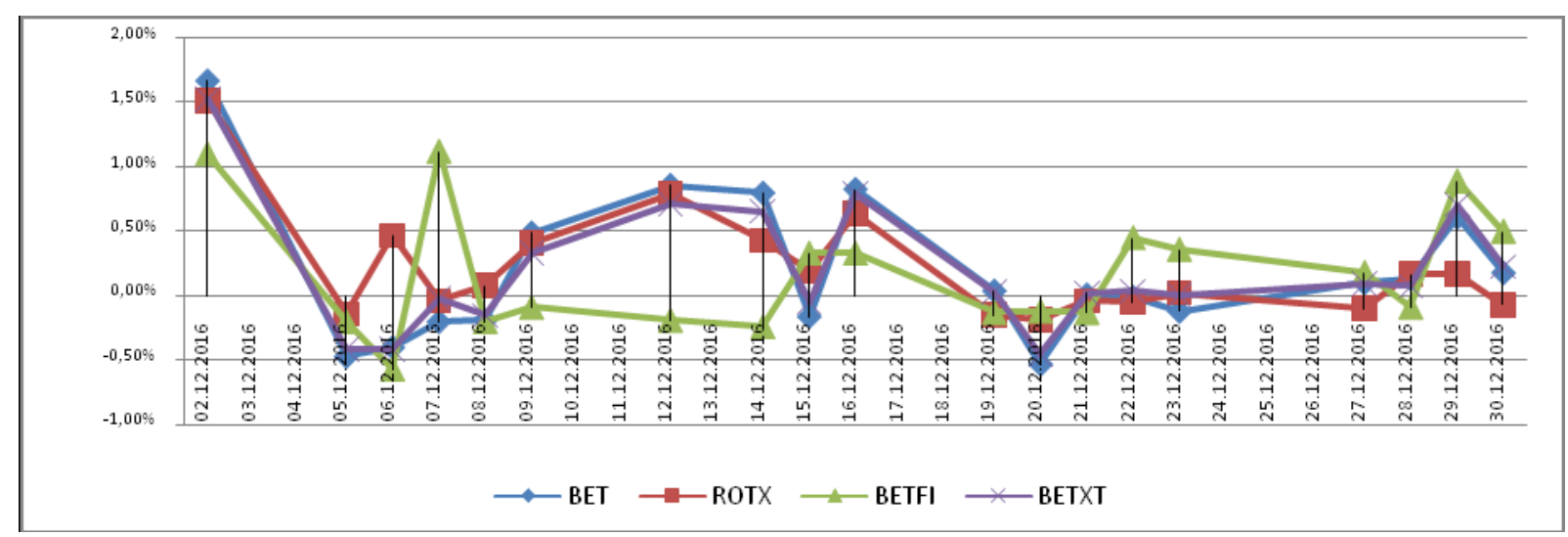

Figure no. 25 Evolution of daily BSE index changes in December 2016 
Regarding the evolution of daily variations, the highest daily variations did not coincide with the moment of the parliamentary elections.

\section{protests}

January-February 2017 - Street

Evolution of the indices analyzed in January-February 2017 is shown in Figures no. 26, 27, 28 and 29:

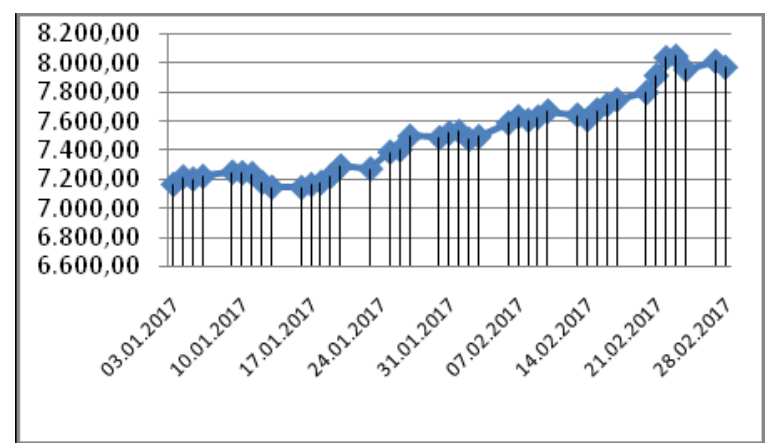

Figure no. 26 BET index evolution in January-February 2017

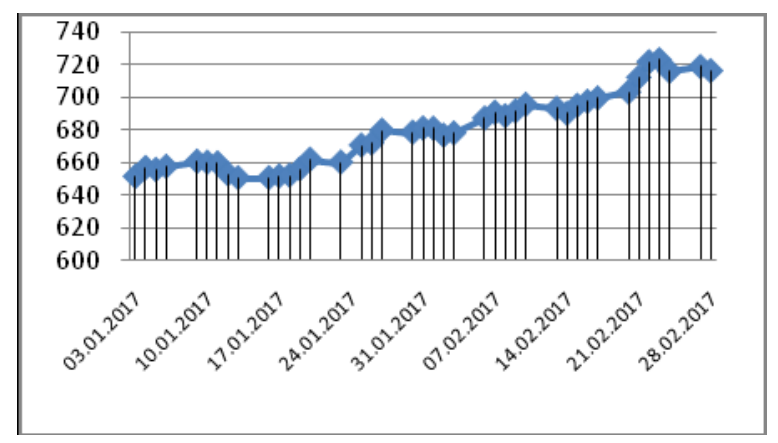

Figure no. 27 BETXT index in January - February 2017

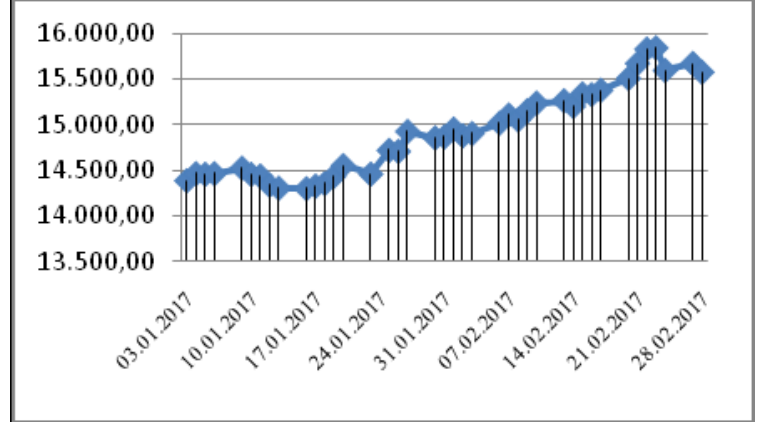

Figure no. 28 ROTX index evolution in January-February 2017

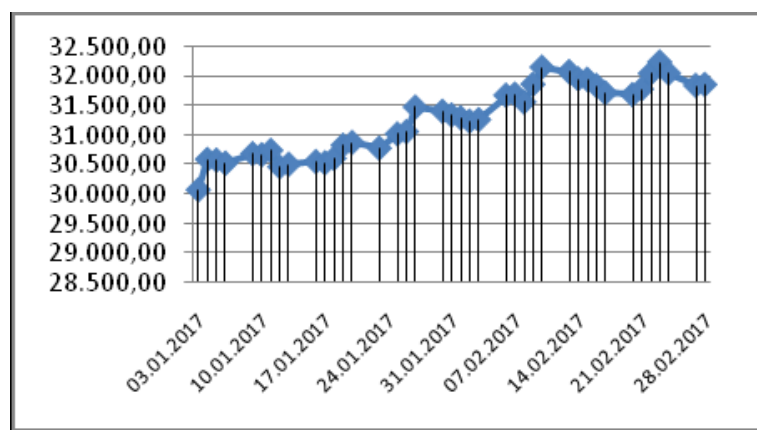

Figure no. 29 BETFI index evolution in January - February 2017

Despite social events, which had the largest magnitude since December 1989, the indices values increases during street protests.

Regarding the evolution of daily variations, these are presented in the Figure no. 30:

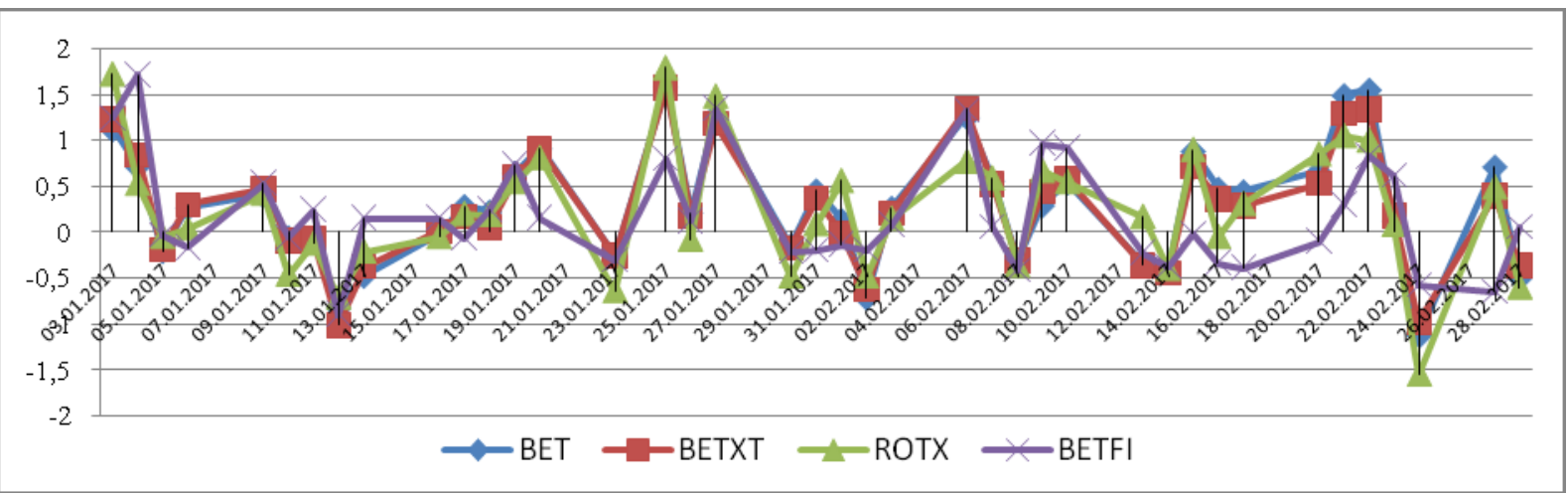

Figure no. 30 Evolution of daily BSE index changes in January - February 2017 
Regarding the evolution of daily variations, the highest daily variations did not coincide with the moments of street protests. The lowest value had been registered before and after these social events.

\section{June 2017 - Government changes}

Evolution of the indices analyzed in July 2017 is shown in Figures no. 31, 32, 33 and 34:

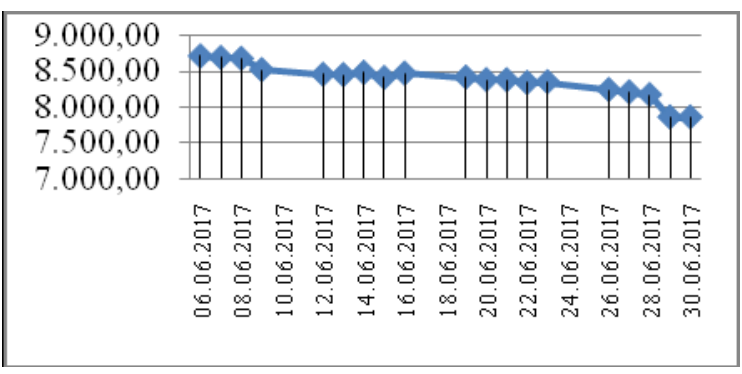

Figure no. 31 BET index evolution in June 2017

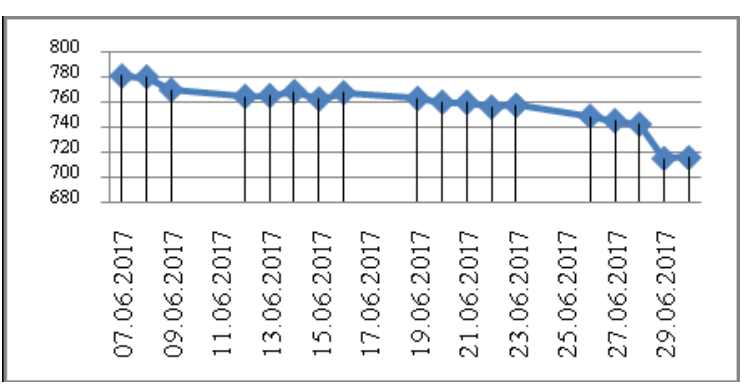

Figure no. 32 BETXT index in June 2017

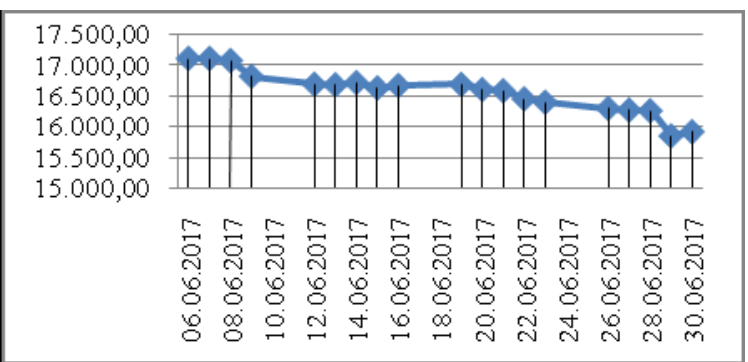

Figure no. 33 ROTX index evolution in June 2017

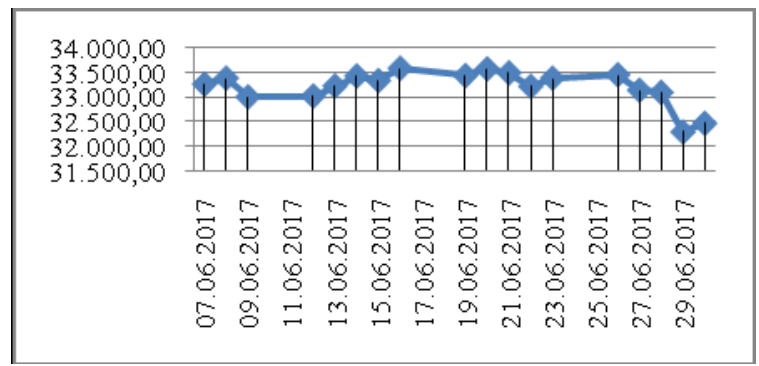

Figure no. 34 BETFI index evolution in June 2017

It is noteworthy that all indices recorded a daily decrease in the period 28-29 June 2017, when Grindeanu Government was dismissed on grounds of inefficiency, ending a new political crisis.

Regarding the evolution of daily variations, these are presented in the Figure no. 35:

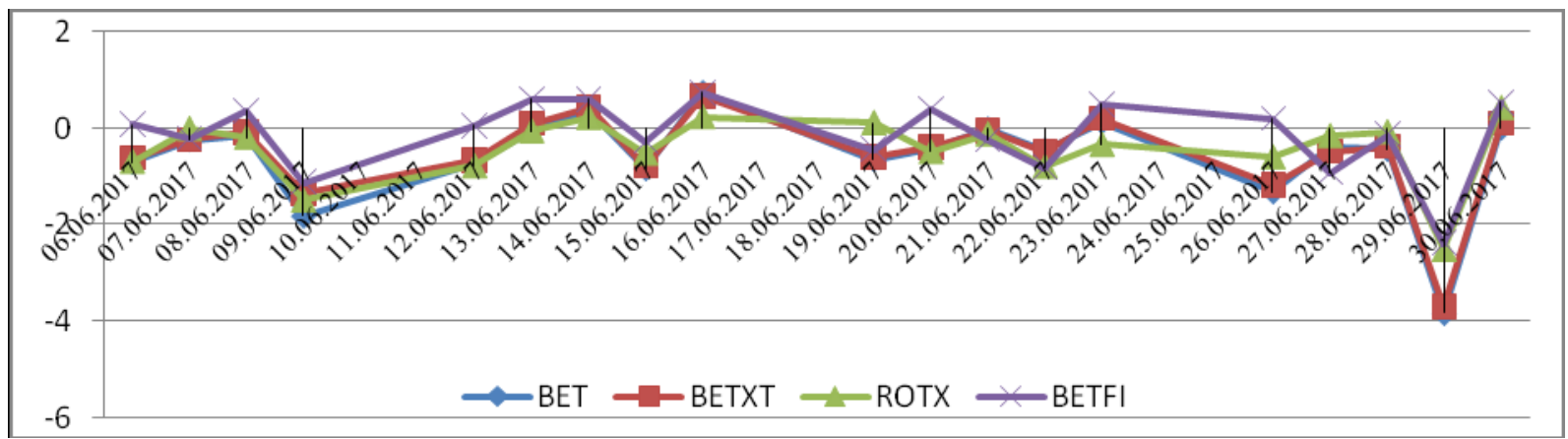

Figure no. 35 Evolution of daily BSE index changes in June 2017 
It is also obviously that the greatest decreases compared to the previous day were recorded for all indices on June $29^{\text {th }}$, 2017, the day when the government was dismissed.

\section{Conclusions}

Between 2014-2017, the political life in Romania was the scene of major events: five Governments were changed, four times due to political crisis. Presidential, local and parliamentary elections took place. At each of those events, the BSE indices reacted differently, recording a wider or smaller variation. The events that generated the strongest declines were Government changes, especially in 2014, (when the USL broke up and the PNL decided to leave the government, the Government of Victor Ponta (2) was dissolved and the Victor Ponta Government (3) was established) and in June 2017 (when Grindeanu Government was dismissed and Tudose Government was established).

Local and parliamentary elections did not have a very strong impact on the indices, considering that the highest daily variations did not coincide with the moment of the local elections. Instead, during presidential elections, each of the analyzed indices was decreasing, the minimum value being recorded at the second ballot. The fall in index values began with the first ballot, on the background of the social and political instability being fueled by the Diaspora's manifestations of voting abroad. The largest decreases compared to the previous day occurred in all cases on the $20^{\text {th }}$ of November 2014, the period that followed the second round of elections and the announcement of the result of the presidential elections.

Considering these developments, we can conclude that common political events such as local and parliamentary elections do not have a major impact on Romanian stock market indices evolution. But when these political changes are based on political or social crises, the variance of the index values is obvious. These evidences allow us to partially validate the research hypothesis, namely that the important social-political events have a obvious impact on the evolution of the Stock Exchange, generating variations in indices quotes, even if the impact is not major and generated variations are not significant, as supposed.

\section{REFERENCES}

Anghelache, G. (2009). Piaţa de capital în context european, Bucureşti: Economică, 495-497.

Dragotă, V., et al. (2008). Piețe și sisteme financiare, București: Editura ASE, 72-73.

Dragotă, M., et al. (2009). Piețe financiare. Structură, instituţii, instrumente, reglementări, București: Editura ASE, 72-73.

Stancu, I. (2007). Finanțe. Piețe financiare şi gestiunea portofoliului. Investiţii directe şi finanţarea lor. Analiza și gestiunea financiară financiară a întreprinderii, ediţia a patra, București: Editura Economică, 219-220.

www.bvb.ro 